\title{
Yhteisnavettayritysten johtamiskäytäntöjä
}

Anna-Maija Minkkinen ${ }^{1,2}$, Seppo Mönkkönen ${ }^{1}$, Kalevi Paldanius ${ }^{1}$, Petri Kainulainen ${ }^{1}$, Pirjo Suhonen ${ }^{1}$

1) Savonia-amk, PL 72, 74101 Iisalmi, etunimi.sukunimi@savonia.fi

2)ProAgria Keski-Suomi, PL 112, 40101 Jyväskylä, anna-maija.minkkinen@proagria.fi

\section{Tiivistelmä}

Maatilojen rakennekehitys jatkuu voimakkaana ja vaatii yhä suurempia investointeja tulevaisuudessa. Suomessa on kuitenkin vielä paljon pieniä ja keskikokoisia maatiloja, jotka haluaisivat jatkaa maidontuotantoa. Useamman tilan yhteinen navetta voisi olla yksi ratkaisumalli näille maitotiloille. Yhteisellä navetalla voisivat pienemmätkin maatilat saavuttaa ison yksikön edut kustannustehokkuudessa ja pysyä kilpailukykyisinä tulevaisuudessa. Monen omistajan yritys asettaa johtamiselle erityisvaatimuksia ja vaatii myös asennemuutosta osakkailtaan verrattuna entiseen maatilayrittämiseen.

Tämän tutkimuksen tavoitteena oli selvittää yhteisnavettayritysten johtamiskäytäntöjen muotoutumista ja sitä, mitkä johtamisen osa-alueet korostuvat yrityksen eri vaiheissa. Keskeistä on myös vastata kysymykseen, mitä yhteisnavettaosakkuus vaatii osakkailtaan ja mitä se heille antaa. Yhteisnavetalla tarkoitetaan kahden tai useamman osakkaan perustamaa maidontuotantoyritystä, jossa tuotetaan maitoa yhteisellä työpanoksella. Yleensä yhteisnavetta omistaa tuotantorakennuksen, eläimet ja niin halutessaan myös nurmenkorjuukoneita. Työt, vastuu ja tulos jaetaan osakkaiden kesken. Mahdollisia yhteisnavettayrityksen yhtiömuotoja ovat avoin yhtiö, kommandiittiyhtiö, osakeyhtiö ja osuuskunta.

Tähän tutkimukseen osallistui viisi eri-ikäistä yhteisnavettayritystä. Kokemuksia johtamiskäytännöistä kartoitettiin haastattelemalla osakkaita. Tarkoituksena oli kerätä kokemusperäistä tietoa yhteisen navettayrityksen johtamisesta neuvonnan käyttöön uusien yritysten suunnittelun tueksi mutta myös olemassa olevien yritysten johtamisen avuksi. Vastaukset analysoitiin sisällönanalyysillä.

Yhteisellä navettainvestoinnilla oli haettu työmäärän keventämistä ja investointiriskin jakamista useamman yrittäjän kesken. Työn mielekkyys lisääntyi uuden teknologian käyttöönoton ja työyhteisön muodostumisen myötä. Työnvuorotusta ja säännöllisiä vapaapäiviä tavoiteltiin suunnitteluvaiheessa ja ne saatiinkin ensimmäisinä toteutetuksi. Myöhemmin vastuita jaettiin omien kiinnostusten, erityistaitojen tai fyysisten rajoitteiden perusteella.

Yhteisnavetta asettaa erityisiä haasteita johtamiselle ja vaatii selvästi yritysmäisempää otetta kuin perinteisen perheviljelmän pyörittäminen. Johtamiseen olisi hyvä saada koulutusta ja harjoitustakin jossain muualla ennen yhteisnavetan perustamista. Henkilökemioiden yhteensopiminen ja tiimityöskentelyn osaaminen näyttäisivät olevan onnistumisen edellytyksiä. Kun työyhteisö voi hyvin, se selviää kuormittavistakin tilanteista yhteisvoimin. Johtamisen eri osa-alueet korostuvat ajan kuluessa. Alkuun strateginen johtaminen on tärkeintä, sen jälkeen operatiivinen johtaminen tulee päällimmäiseksi muutamiksi vuosiksi, jonka jälkeen on taas aika tarkastella strategisia valintoja uudelleen.

Tämän tutkimuksen jälkeenkin avoimiksi kysymyksiksi jäivät: Kuinka hyvin kumppanit pitää tuntea, jotta uskaltaa ruveta yhdessä yrittämään? Miten paljon ympäristö vaikuttaa omilla asenteillaan ja onko niitä mahdollista muuttaa?

\section{Asiasanat}

Yhteisnavetta, osakkuus, johtaminen, maidontuotanto 


\section{Johdanto}

Maatalouden tilarakenne on muuttunut huomattavasti Suomen EU-jäsenyysaikana. Kotieläintilojen määrä on vähentynyt ja kasvinviljelytilojen lisääntynyt. Vuonna 2011 maidontuotantotiloja oli enää 17 prosenttia kaikista maataloustukea hakeneista tiloista. Maitotilojen lukumäärä on vähentynyt 6,7 prosentin vuosivauhdilla vuodesta 1995 . (Niemi \& Ahlstedt 2012, 15-16.)

Suomalaiset maitotilat ovat vielä varsin pieniä verrattuna esimerkiksi Tanskan maitotiloihin, jossa nyt lähes kaikki maito tuotetaan yli 50 lehmän tiloilla. Suomessa vasta 26 prosentilla tiloista oli yli 50 lehmää vuonna 2010. Vastaava tilanne oli Ruotsissa jo vuonna 1995. Koska Suomen tuotantojakauma vastaa aika hyvin Ruotsin jakaumaa, voidaan tästä päätellä, että vuonna 2020 Suomessakin maitoa tuotetaan yli 50 lehmän karjoissa suunnilleen puolet kokonaistuotannosta. (Pyykkönen, Lehtonen \& Koivisto 2012, 8.)

Investoinnit keskittyvät yhä harvemmille tiloille ja ovat isompia kuin aikaisemmin. Työn määrä kasvaa sellaisiin mittasuhteisiin, ettei sitä enää hallita viljelijäpariskunnan työpanoksella. Tilakoon kasvulla saavutettava hyöty on kuitenkin vielä kustannuksia suurempi maidontuotannon keskeisillä tuotantoalueilla, joten se kannustaa investoimaan isompiin yksiköihin. Kehitys näyttäisi Pellervon taloustutkimuksen tekemän ennusteen mukaan jatkuvan samansuuntaisena vielä ainakin seuraavat kymmenen vuotta. (Pyykkönen ym. 2012, 7.) Tämä tarkoittaa maidontuotannon muuttumista entistä yritysmäisemmäksi. Ulkopuolista työvoimaa ja yhteistyötä tullaan tarvitsemaan isoissa yksiköissä yhä enemmän ja se asettaa yrittäjille uusia haasteita johtamisen ja varsinkin henkilöstöjohtamisen saralla. Monen ihmisen työskennellessä yhdessä lisääntyvät sekä sosiaalinen vastuu että riski. Yritystoiminnan kasvun myötä syntyy myös tarve turvata yksityisomaisuus. (Österman 2007 , 7.) Onko maataloudessa menossa nyt kulttuurinen muutos, jossa viljelijän tie alkujaan talonpojasta maataloustuottajan kautta käy maatalousyrityksen toimitusjohtajaksi, vai käykö? (Hangasmaa 2002, 47.)

Useamman tilan yhteinen navetta voisi olla yksi ratkaisumalli jatkamishaluisille maitotiloille. Yhteisnavetoissa olisi mahdollisuus kehittää maidontuotantoa, pitää kustannustehokkuus hyvänä ja työajan käyttö järkevissä rajoissa. Yhteisellä navetalla voisivat pienemmätkin maatilat saavuttaa ison yksikön edut kustannustehokkuudessa ja pysyä kilpailukykyisinä tulevaisuudessa. Yhteisnavetan johtaminen on kuitenkin vaativampaa kuin perinteisen perheviljelmän.

Tässä tutkimuksessa selvitetään yhteisnavettayritysten johtamiskäytäntöjen muotoutumista ja sitä mitkä johtamisen osa-alueet korostuvat yrityksen eri vaiheissa. Keskeistä on myös vastata kysymykseen, mitä yhteisnavettaosakkuus osakkailtaan vaatii ja mitä se heille antaa. Taustaoletuksena on, että hyvät johtamiskäytännöt tuottavat hyvää tulosta, vaikka sitä ei pystytä tässä tutkimuksessa selvästi osoittamaankaan. Hyvällä tuloksella tarkoitetaan niin henkistä, fyysistä kuin taloudellistakin hyvinvointia.

\section{Aineisto ja menetelmät}

Tutkimuksen kohderyhmänä oli viisi yhteisnavettaa, jotka oli perustettu kahden tai useamman olemassa olevan tilan yrittäjien kesken. Yrityksen sijainnilla ei ollut merkitystä ja tutkimukseen osallistuneet yritykset sijaitsevatkin viiden eri maakunnan alueella. Haastateltavat yritykset valittiin harkinnanvaraisella otannalla, koska tarkoituksena oli koota mahdollisimman monipuolista tietoa yhdestä yrityksestä tai yhdeltä henkilöltä. Tutkimustyyppi oli empiirinen ja -menetelmä kvalitatiivinen. Tiedonkeruumenetelmänä oli teemahaastattelu. Kysymykset jakautuivat kuuteen teemaan: yrityksen puitteet ja resurssit, yhteisnavettayrityksen perustamisella alun perin tavoitellut hyödyt, toiminnan johtaminen käytännössä, yrityksen tulevaisuuden suunnitelmat, yhtiön hallinnointi ja päätöksenteko, omat kokemukset ja tyytyväisyys. Haastattelut tehtiin loka - joulukuussa 2012 ja tammikuussa 2013 vierailemalla henkilökohtaisesti yrityksissä. Haastatteluihin osallistui 1-3 henkilöä yritystä kohti. Haastattelut nauhoitettiin, aineisto litteroitiin ja analysoitiin sisällönanalyysillä.

\section{Tulokset ja tulosten tarkastelu}

Neljä haastatelluista yrityksistä oli avoimia yhtiöitä ja viides oli osakeyhtiö. Yhteisnavetta voisi toimia kommandiittiyhtiönä tai osuuskuntanakin, mutta sellaisia maidontuotantoyrityksiä ei tähän tutkimukseen löytynyt. Karjakoko vaihteli 70-220 lehmään. Kolmessa navetassa oli asemalypsy ja kahdessa robottilypsy.

Osakkaista naisia oli kolme ja miehiä neljätoista. Iät haastatteluhetkellä vaihtelivat 26-53 vuoteen. Haastatteluun osallistui yhteensä kymmenen osakasta viidestä eri yrityksestä. Koulutustausta vaihteli käytännön työssä oppimisesta korkeakoulututkintoihin. Yritysten osakkaista yksi oli agronomi, yksi maa- ja metsätieteiden maisteri, yksi maa- ja metsätieteiden kandidaatti, viisi agrologia, kaksi maatalousteknikkoa, seitsemän maatalouden perustutkinnon suorittanutta ja kahdella oli muu kuin maatalouden ammattitutkinto. 
Erityisosaamista oli kertynyt käytännössä ja ainakin kahdessa yrityksessä mainittiin erikseen, että heillä on taitavia koneenkorjaajia omasta takaa. Palkattua työvoimaa yrityksissä oli 1-3 henkilöä. Vain automaattilypsytiloilla ei ollut palkattua työvoimaa. Henkilöstöjohtaminen koettiin hankalaksi ja se oli vaatinut opettelemista eräässä yrityksessä, jossa käytettiin palkkatyövoimaa.

Yrityskumppanit olivat vaihtuneet suunnitteluprosessin aikana, eivätkä alkuperäiset suunnitelmat toteutuneetkaan kuin kahdessa yrityksessä. Suunnitteluprosessi kesti useita vuosia. Osakastilojen etäisyys toisistaan vaihteli lähinaapuruudesta noin 20 kilometriin. Osalla yrityksistä oli tarkat osakassopimukset, mutta osa oli tyytynyt vain yhtiösopimuksen lakisääteiseen tasoon. Sopimuksia ei muistettu tarkkaan, eikä niitä otettu tarkemmin esille haastatteluissa. Kun yhteistyö toimii, sopimukset vaikuttavat vain taustalla, eikä niitä koeta tärkeiksi jokapäiväisessä elämässä. Haastatteluissa kävi ilmi, että tahtotila yhteisnavetan perustamiseen pitää olla lähtöisin yrittäjistä itsestään, sitä ei voi mikään ulkopuolinen taho sytyttää. Yhdellä haastatelluista yrityksistä oli pitkä kokemus yhteistyöstä, toisen yrityksen osakkailla oli ennestään koneurakointiosuuskunta, mutta kolme muuta yritystä olivat aloittaneet yhteistyön navetan perustamisella.

Yrityskoko oli muotoutunut osakkaiden hallinnassa olevan peltopinta-alan perusteella. Yhdellä yrityksellä oli rehuntuotantosopimuksia ympäröivien tilojen kanssa. Muilla yrityksillä koko rehuntuotantoon tarvittava pinta-ala oli joko osakkaiden tai yhtiön hallinnassa.

Maito oli päätuote kaikissa yrityksissä. Tuotantotavoitteet vaihtelivat $600000-2000000$ litraan. Meijerimaidon pitäminen parhaassa E-luokassa oli itsestäänselvyys kaikissa yrityksissä. Sillä on suuri rahallinen vaikutus, kun kyseessä on iso maitomäärä. Lihaa tuotettiin poistoeläimistä, sonnivasikat myytiin pienenä pois. Kantavia hiehoja myytiin eloon satunnaisesti. Tuotantomuoto oli yhdessä yrityksessä luonnonmukainen, muilla tavanomainen maidontuotanto. Rehuntuotannossa käytettiin osittain ulkopuolisten urakoitsijoiden palveluja ja osa teki peltotyöt kokonaan oman henkilökunnan voimin. Tähän vaikuttivat peltopinta-ala ja oman henkilökunnan määrä. Neljässä yrityksessä oli aperuokinta, yhdessä erillisruokinta.

Osakkaat sopivat asioita suullisesti päivittäisten töiden lomassa. Investointikysymykset käsiteltiin yhtiökokouksissa, joita pidettiin kahdessa yrityksessä pari kertaa vuodessa, kahdessa kerran vuodessa ja yhdessä noin neljännesvuosittain. Päätösten tekeminen on hitaampaa monen omistajan yrityksessä verrattuna perheyritykseen, mutta kehittämisestä oli päästy yksimielisyyteen kaikissa tutkimukseen osallistuneissa yrityksissä.

Kannattavuus on koko toiminnan perusedellytys. Sillä on vaikutuksia myös työhyvinvointiin. Kannattavuuden ollessa hyvä, voidaan palkata lisätyövoimaa, ostaa palveluja ja lisätä omaa vapaa-aikaa tai palkkaa sekä suunnitella yrityksen kehittämistä ilman suurten riskien ottoa. Haastatteluissa kävi ilmi, että kannattavissa yrityksissä rahalla on selvästi henkilösuhteita parantava ja rauhoittava vaikutus. Hyvä tulos pistää osakkaat yrittämään vielä enemmän ja paremmin, siitä syntyy positiivinen noste koko yritykseen.

\section{Yrityskulttuuri ja toimintatavat kehittyvät}

Yhtiön taloustilanteen esitteleminen muille osakkaille kirjallisesti oli toimitusjohtajan vastuulla ja se vaihteli välillä kerran kuukaudessa - kerran vuodessa. Keskustelua yhtiön taloustilanteesta käytiin toki useammin ja epävirallisemmin töiden lomassa. Toimitusjohtajan sana painoi investointien suunnittelussa eniten. Hänellä oli tieto siitä minkä kokoisiin hankintoihin budjetissa on varaa. Kolmessa yrityksessä ei ollut erikseen nimettyä toimitusjohtajaa vaan kirjanpidosta ja maksuliikenteestä vastaava osakas kertoi toisille taloustilanteesta ja maksuvalmiudesta. Niissä yrityksissä, joissa toimitusjohtaja oli nimetty, hän oli ollut alusta asti sama henkilö, eikä tarvetta muutokseen nähty. Yhteisnavettayrityksen johtaminen ei välttämättä näyttäisi vaativan korkeakoulutasoista tutkintoa, mutta toimitusjohtajan tehtävissä toimivalle osakkaalle yritystalouden koulutuksesta on varmasti hyötyä.

Vastuuntunto oli kaikkien haastateltujen osakkaiden mielestä hyvä: "Isännän askel on aina pitempi kuin työntekijän." Toimivan vastuunjaon edellytys on luottamus toisen osaamiseen ja siihen, että työt tulevat tehdyksi. Silloin työnjaolla saadaan aikaan todellista työn kevennystä. Tämä vaatii aikaa eikä tunnu toteutuvan vielä ensimmäisinä toimintavuosina. Ensiksi näyttäisi toteutuvan fyysisen työmäärän jakaminen ja vasta vähän myöhemmin onnistuu henkisen vastuun jako. Jo kahden vuoden toiminnassa olon jälkeen todettiin, että nyt rutiinit ovat aika hyvin loksahtaneet kohdilleen. Onnistumisen edellytyksenä pidettiin henkilökemioiden toimimista ja olennaisen erottamisen taitoa epäolennaisesta. Vastuunjaon periaatteena oli, että kaikki työ on samanarvoista. Tehtävät olivat eriytyneet taloudenhallinnan tehtäviin, suunnitteluun, tuotosseurannan ja eläinrekisterin ylläpitämiseen, siemennykseen ja eläinterveyteen, koneiden huoltoon ja korjaamiseen. Päivittäiset työt, kuten lypsäminen, ruokinta, vasikoiden hoito ja puhtaanapito kuuluivat kaikille mutta niissä voitiin vuorotella. Monialaosaaminen omassa yrityksessä on etu ja erityisosaamista kannattaa hankkia mahdollisuuksien mukaan. 
Lypsäminen lypsyasemalla on fyysisesti rasittavaa. Sen ei pitäisi kestää 1,5 tuntia kauempaa karjakoosta riippumatta. Kun se kuitenkin kesti kauemmin, oli ongelma eräässä yrityksessä ratkaistu niin, että vanhemmat osakkaat lypsivät vain yhden lypsyn päivässä. Toisella automaatiolypsytilalla vaihdettiin työtehtäviä vuoroviikoin. Vuorottelu koski vasikoiden hoitoa ja lehmien ruokintaa. Pitempään toiminnassa olleissa yrityksissä oli panostettu henkilöstön hyvinvointiin kannustamalla liikuntaan vapaa-ajalla tai järjestämällä ohjattuja jumppatuokioita työpaikalla.

Varahenkilöjärjestelmä oli luotu jokapäiväisiin toimintoihin oman henkilöstön kesken. Sijaisavun saamisen mahdollisuus lomitusjärjestelmän kautta koettiin turvaksi pitempiaikaisessa tarpeessa. Harvemmin tapahtuviin toimintoihin, kuten esimerkiksi vuositason suunnitelmiin ja verotilinpäätöksen laadintaan ostettiin avuksi neuvojia, jolloin he toimivat myös varahenkilöinä näissä töissä.

\section{Riskit hallintaan}

Riskienhallinnasta todettiin, että yhteisnavetassa ei tule liikaa vastuuta ulkopuoliselle, koska aina on joku isäntäväestä mukana. Hetken aikaa jaksetaan pienemmälläkin miehityksellä, ellei esimerkiksi sijaisapua saada heti. Lypsyrobotin vikapäivystystä kiiteltiin. Vikojen korjaus ja muut ongelmat on mukavampi ja turvallisempi hoitaa yhdessä verrattuna entiseen tilanteeseen, yksin yrittämiseen.

Rehuomavaraisuus vaihteli vain nurmirehun tuotannosta 1,5 vuoden omavaraisuuteen kaikessa kotoisessa rehussa. Pellon saatavuus vaihteli suuresti paikkakunnittain. Kaikissa yrityksissä pyrittiin hyvään rehuomavaraisuuteen. Pellon ostoa tai vuokrausta suunniteltiin.

Viime vuosina oli vähennetty vierailijoiden vastaanottoa eläintautien leviämisen ehkäisemiseksi. Eläinten ostoa oli pyritty välttämään lukuun ottamatta aloitusvaihetta, jolloin tuotannon ylösajon takia oli pakko hankkia eläimiä myös ulkopuolisilta. Taloudellisen riskin arvioimiseen ei otettu oikein kantaa, eikä haastatteluissa käynyt ilmi oliko tuotantokustannuslaskelmia tehty tai millaisen maidon hinnan alenemisen maksuvalmius kestää.

\section{Tuotannon kasvattaminen ja tulevaisuuden suunnitelmat}

Tulosta jaettiin palkkaa nostamalla, pellon vuokraa maksamalla, koneurakoinnista maksamalla, rehua ostamalla ja yksityisotoilla, jotka olivat joko säännöllisiä tai niitä tehtiin osakkaan tarpeen mukaan. Yritysten tulos koostui maidon myynnistä ja peltotuista. Eläinmyynnillä ei ollut kovin suurta vaikutusta. Yksi yritys myi urakointipalveluja myös ulkopuolisille. Tulostavoitteista ei ollut aivan selkeää kuvaa kaikissa yrityksissä tai he eivät sitä halunneet kertoa.

Pitempään toimineissa yrityksissä oli saavutettu tasaisen tuloksen tekemisen vaihe ja velkoja oli saatu maksettua pois. Tilanne vaikutti turvalliselta, mutta tulosta ei haluttu sen enempää kehua. Mainittiin vain, että "ei tällä rikastumaan pääse, mutta pärjää" ja "kaikille riittää rahaa, mutta kuitenkaan sitä ei oo sillei ylen määrin jaettavaksi". Aloitusvaiheessa olevat mainitsivat, että tiukoilla ollaan ja tehdään tappiota alkuun. Yrityksen kuolemanlaaksosta oli tultu yli metsärahojen avulla ja tekemällä itse enemmän työtä. Tuotanto oli saatu kasvatettua täyteen mittaansa noin puolentoista vuoden kuluttua investoinnista. Tavoitteena oli ollut vuosi tai jopa alle vuosi. Vanhemmissa yrityksissä tuotannon ylösajo oli kestänyt noin kolme vuotta.

Laatujärjestelmä oli valmis ja auditoitu vain yhdessä yrityksessä. Omavalvontasuunnitelma ja työohjeita oli kirjallisina muissa yrityksissä. Ilmoitustaulu ja päiväkirjan tyyppinen viestintävihko olivat käytössä kahdessa yrityksessä. Päiväsaikaan tiedonsiirto tehtiin kuitenkin mieluiten suullisesti järjestämällä työvuorot hieman päällekkäin. Eräässä yrityksessä työvuorossa olevat kokoontuivat palaveriin taukohuoneeseen aina samaan aikaan joka päivä.

Oman yrityksen imagosta, siitä miltä yritys näyttää ulospäin, ei oikein oltu tietoisia. Maatalousharjoittelijoita oli kuitenkin ollut vaihtelevasti, joten kiinnostus yrityksiä kohtaan oli herännyt oppilaitoksissa. Ulkopuoliset tunnustukset eivät muutenkaan näytelleet suurta osaa, eikä niitä erikseen tavoiteltu. Mainittiin kyllä, että mukavaltahan ne tuntuisivat.Yksi yritys tiedosti hyvin tarkkaan merkityksensä asiakkaille. Muissa sitä ei ollut erikseen mietittykään.

Visiota ja toiminta-ajatusta haastatellut yrittäjät eivät osanneet kovin tarkkaan kuvata. Näkemys yhtiön tulevaisuudesta oli kuitenkin olemassa. Pari vuotta toiminnassa olleissa yrityksissä oli tuotannon kasvuvaihe vielä meneillään ja siihen keskityttiin täysillä. Aivan tarkkaa kuvaa tuotannon tavoitteista ja taloudellisesta tuloksesta pitkällä aikavälillä ei kuitenkaan ollut. Tulevaisuuden tavoitteista mainittiin pellon ostaminen ja varautuminen rakentamaan hiehoille kasvatuspaikat, jos tällä hetkellä oleva sopimuskasvatus päättyy.

Noin kymmenen vuotta toiminnassa olleet yritykset olivat saavuttaneet tasaisen tuloksen tekemisen vaiheen. Osakkaat miettivät jo oman työuran päättymistä ja sukupolvenvaihdosta tai jopa yhtiön myymistä ulkopuoliselle mahdollisuutena päästä itse eläkkeelle. Yhtiön nähtiin kuitenkin jatkavan tuotantoaan, vaikka oma työura loppuukin aikanaan. 
Kouluttautumistarpeista nousi esille keinosiemennyksen toimilupakurssit, joita oli jo käyty tai sitten ne olivat lähitulevaisuuden suunnitelmissa. Pitempiaikaisia koulutussuunnitelmia osakkailla ei ollut. Työntekijöiden osallistumisesta muutaman päivän kursseille koettiin olleen hyötyä. Uuden teknologian käyttöönotosta oli selvitty laitevalmistajien etukäteen järjestämillä muutaman päivän kursseilla ja käytännössä opettelemalla. Puhelinneuvontaa oli ollut hyvin saatavilla käyttöönoton jälkeenkin.

Osakkaiden määrän mahdollisesta lisäämisestä oli puhetta yhdessä yrityksessä. Muissa vaihtuvuutta voisi tulla sukupolvenvaihdoksen kautta.

Investointien pohtimista useamman henkilön kanssa ei pidetty haitallisena, vaikka päätöksenteko sillä tavalla hidastuukin. Yrityksen kehittämisestä oli kuitenkin päästy yhteisymmärrykseen. Henkilökohtaista vastuuta koko yhtiön veloista ei pidetty ongelmana. Yhdessä yrityksessä rahoittaja oli perustamisvaiheessa suositellut avointa yhtiötä vakuuksien järjestämisen takia. Lomaoikeudesta ja MYEL-vakuutuksesta haluttiin pitää kiinni. Sijaisavun saaminen ja vuosiloman järjestyminen kunnallisen lomituksen kautta koettiin tärkeäksi. Tämä oli vaikuttanut jopa yhtiömuodon valintaan.

Parhaiten onnistuneina asioina pidettiin työyhteisön muodostumista ja säännöllisiä vapaapäiviä. Myös erikoistuminen oman kiinnostuksen mukaisiin työtehtäviin toi lisää mielekkyyttä työntekoon. Ajan kuluminen vaikuttaa työtehtävien tarkentumisiin ja erikoistumisiin. Aluksi kaikki osakkaat osallistuivat navetan kaikkiin töihin. Kun rutiinit ovat sujuvia, voidaan tehtäviä myöhemmin jakaa kiinnostusten mukaan kuitenkin niin, ettei mikään tehtävä jää hoitamatta sen vuoksi, ettei se kiinnosta ketään.

Tuotantotavoitteissa mainittiin onnistumisina yli 10000 kg:n keskituotos, maksuvalmiuslaskelmassa olleen meijerimaitomäärätavoitteen ylittyminen jo toisena toimintavuotena ja tuotantolukujen tasainen nousujohteisuus. Ruokinnan onnistuminen suunnittelusta toteutukseen, sen yksinkertaisena mutta toimivana pitäminen koettiin onnistumisena, kuten muunkin toiminnan pitäminen selkeänä ja tehokkaana. Työmäärän väheneminen automaattilypsyyn siirryttäessä ja hyvä kannattavuus sekä riittävä korvaus työstä olivat myös tyytyväisyyden aiheita.

\section{Johtopäätökset}

Strategisen suunnittelun onnistuminen toiminnan aloitusvaiheessa helpottaa operatiivista johtamista tulevaisuudessa, siksi siihen kannattaa käyttää aikaa. Osakassopimusten laadinnassa on hyvä käyttää apuna kokenutta yritysneuvojaa. Yhtiömuodolla ei näyttäisi olevan suurtakaan merkitystä käytännön toiminnassa, päätöksentekoon ja hallinnointiin se kyllä vaikuttaa. Yhteistyöstäkään ei tarvitse välttämättä olla aikaisempaa kokemusta, mutta henkilökemioiden yhteen sopimisella ja toistensa toimintatapojen tuntemisella on ratkaiseva merkitys yrityksen menestymisen kannalta. Osakkaiden iällä ja koulutustaustalla ei taas näyttäisi olevan suurtakaan vaikutusta. Sopiva porukka on tärkeämpi ja porukasta pitää löytyä johtaja.

Säännölliset vapaapäivät olivat se ensimmäinen tavoite, mihin tähdättiin yhteisellä navetalla. Niistä kannattaa aloittaa. Toisen osaamista pitää arvostaa ja muistaa, että kaikki työ on samanarvoista. Useamman omistajan yrityksessä vastuunjakoa helpottaa, jos osakkailla on ennestään erilaista osaamista tai kiinnostusta eri asioihin. Tilanteessa, jossa kaikki tekevät kaikkea yhtä aikaa, voi olla vaikea kenenkään nousta johtajaksi ilman, että se aiheuttaa ristiriitoja osakkaiden välille. Eräs osakas kiteytti asian näin: "Jos kaikki olis karjaihmisiä, niin sillon vois tulla tyhjänpäiväsistä asioista riitaa”.

Yhteisnavetta mahdollistaa työtehtävien eriytymisen henkilökohtaisten kiinnostusten mukaan. Se, että saa toteuttaa itseään auttaa jaksamaan ja pysymään terveenä työssä. Jo toiminnan käynnistysvaiheessa vastuualueiden olisi hyvä olla selvillä. Se nopeuttaa työajan käytön asettumista tavoitellulle tasolle. Jos mahdollista, kannattaa osaamista hankkia jo etukäteen, tyypillisenä esimerkkinä keinosiemennyksen toimilupakurssit. Yrityksessä olisi hyvä olla myös liikekirjanpidon osaamista alusta alkaen. Tasaisen tekemisen vaiheessa ja kannattavuuden ollessa riittävän hyvä, voidaan aikaa käyttää oman osaamisen kehittämiseen. Tässä voisi olla mahdollisuus osallistua esimerkiksi henkilöstöjohtamiseen liittyvään koulutukseen.

Tuotannon aloitusvaiheessa meijerimaidon lisääntyminen eläinmäärän kasvun myötä voi luoda väärän mielikuvan tuotannon tehokkuudesta. Neuvojahavaintojeni mukaan laajentaneilla tiloilla ei tule seurattua keskituotoksen kehitystä ja sen rajukin lasku voi tulla yllätyksenä. Tulos vaikuttaa ristiriitaiselta, koska samaan aikaan meijerimaitomäärä on kasvanut totutuista lukemista.

Laatujärjestelmän luominen tai entisen päivittäminen auttaisi jäsentämään omaa toimintaa ja sen myötä tulisi myös pohdittua yrityksen toiminta-ajatusta, arvoja ja visiota tarkemmin. Jokapäiväisessä työssä olisi hyvä olla reaaliajassa elävä päiväkirjan tyyppinen muistiinpanovihko tai muistitaulu taukohuoneessa ja kaikkien pitäisi myös osata käyttää sitä. Se ei korvaa tietenkään suullista kommunikointia, mutta kun muistiin ei ole oikein luottamista, niin asioita voidaan tarkistaa paremmin, kun ne on kirjattu johonkin. 
Rahalla on rauhoittava vaikutus ja kannattavuus on hyvinvoinnin edellytys. Yrityksen pitää tehdä hyvää tulosta, jotta sillä on menestymisen ja kehittymisen mahdollisuudet tulevaisuudessa. Rahan avulla saadaan pidettyä työmäärä kohtuullisena ja henkilökunta tyytyväisenä. Yritykseen on myös helpompi saada työntekijöitä, kun pystytään maksamaan kilpailukykyistä palkkaa. Hyvän tuloksen tekemisellä saattaa tosin olla jopa laiskistuttava vaikutus. Ollaan tyytyväisiä nykytilanteeseen, eikä pian huomatakaan, kun on jääty kilpailukyvyssä jälkeen muista vastaavankokoisista yrityksistä. Yrityksen olisi kehityttävä ja seurattava aikaansa koko ajan. Tämä ei välttämättä tarkoita laajentamista. Strategiaa pitäisi tarkastella määräajoin tasaisen tuloksen tekemisen vaiheessakin. Se vaatii yrityksen ylimmältä johdolta vision uudistamista tai ainakin entisen kirkastamista tarpeen mukaan. Sidosryhmätyössä asiakkaiden ja yhteistyökumppaneiden kanssa pysyy kehityksessä mukana ja sitä pitäisikin katsoa myös oman osaamisen ja yrityksen kehittämisen näkökulmasta, ei vain yhteiskunnallisena osallistumisena tai velvollisuutena.

Uusia strategioita on tarkasteltava ennakkoluulottomasti. Yhtenä uutena strategiana yrityksen kehittämistä ajatellen voisi olla kasvinviljelytilan ottaminen osakkaaksi kotieläinyritykseen. Osakeyhtiössä se onnistuisi helposti myymällä osakkeita. Kasvinviljelytilan oleminen osakkaana vaikka pienelläkin osuudella toisi varmuutta rehuntuotantoon ja saataisiin aikaan sitovampia tuotantosopimuksia. Samalla se loisi turvallisuutta molemmille osapuolille, kun rehun laatu ja toimitusvarmuus paranisivat. Luonnonmukainen tuotanto, bioenergian tuotanto ja energiaomavarainen maatila voisivat myös olla tulevaisuuden visioita. Yhteiskunnassa tapahtuvat arvomuutokset on hyvä ottaa huomioon omassa yritystoiminnassa, niiden ei tarvitse olla pelkästään uhkia vaan ne voivat olla myös mahdollisuuksia.

Yrityksen johtajan on oltava sama paperilla ja käytännössä. Oman haasteensa yhteisnavettayrityksille tuovat sukupolvenvaihdokset. Parhaimmillaan uuden osakkaan mukaantulo antaa uutta sysäystä ja tuo uusia ideoita yrityksen kehittämiseen. Yrityksessä olisikin hyvä olla eri-ikäisiä osakkaita, jolloin sukupolvenvaihdokset virkistävät johtamista säännöllisin välein, eikä kaikki mene kerralla uusiksi. Yrityksen perustaja tai perustajat luovat yrityskulttuurin yrityksessään ja vaikuttavat siihen joka tapauksessa. Vaarana on, että vahvaan johtohahmoon turvaudutaan liikaakin, eikä kyseenalaisteta toimintatapoja tai tavoitteita pitkiin aikoihin. Tämän näkyy maatilayrityksissä muutenkin, eikä se ole yhteisnavettayritysten erityispiirre. Vahvan johtajan pois jääminen sekoittaa pakkaa ja aiheuttaa uudelleenjärjestelyjä yrityksessä. Entinen johtaja saattaa jäädä yrityksen henkiseksi johtajaksi, eikä osaa luovuttaa päätösvaltaa seuraajalleen. Neuvojakokemukseni mukaan maatiloilla johtaminen on usein yhden ihmisen varassa. Johtaminen henkilöityy ja johtajanvaihdos voi olla hyppy tuntemattomaan. Vaarana on, että entinen johtaja pyrkii vaikuttamaan voimakkaastikin uuden johtajan toimintaan aiheuttaen näin ristiriitoja entisen ja uuden johtajan välille.

Henkilöstön hyvinvoinnilla on ratkaiseva merkitys yrityksen tulokseen. Vapaa-ajan järjestäminen näyttäisi olevan tärkeämpää kuin suuremman palkan ansaitseminen sen jälkeen kun omasta mielestä kohtuullisen toimeentulon raja on saavutettu. Työilmapiirin hyväksi kannattaa tehdä töitä, sillä henkilöstöä johdetaan kannustamalla ja palkitsemalla. Yhteisnavettayrityksen osakkaat ovat itse sekä johtajia, että työntekijöitä. Silloin toisen kiittäminen ja kannustus saattavat helposti unohtua. Kun tunnelma on rentoutunut ja avoin, voidaan kritiikkiäkin antaa ja vastaanottaa ilman, että aletaan varoa omia sanomisia. Omia pieniä palkintoja ja huomionosoituksia kannattaa keksiä, juhlia vaikka kakkukahveilla jonkun tietyn tavoitteen saavuttamista. Tulospalkkiot tai ylimääräiset lomapäivät voisivat olla vielä tuntuvampia palkintoja. Huumoria saa ja pitääkin viljellä.

\section{Kirjallisuus}

Hangasmaa, L. 2002. Maa, tila ja talous - EU-suomalaisen maanviljelijän jatkuvuuden luomisen prosessit muutoksen ajassa. Jyväskylän yliopisto, etnologian laitos. Pro gradu -tutkielma. Jyväskylän yliopisto.

Niemi J.\& Ahlstedt J. (toim.) 2012. Suomen maatalous ja maaseutuelinkeinot 2012. MTT Taloustutkimus. Pyykkönen, P., Lehtonen, H. \& Koivisto, A. 2010. Maatalouden rakennekehitys ja investointitarve vuoteen 2020. PTT työpapereita 125. Pellervon taloustutkimus.

Österman P. 2007, Yritysmuodon valinta. Teoksessa: Enroth, A., Österman P. \& Harmoinen T. (toim.) Maatilayrityksen yhtiöittäminen. Tieto tuottamaan sarja julkaisuja n:o 120. ProAgria Keskusten Liitto. 